Scholedge International Journal of

Management \& Development

ISSN 2394-3378, Vol.05, Issue 11

Pg 121-131.

DOI URL: http://dx.doi.org/10.19085/sijmd051101
Published by: Scholedge Publishing www.theSCHOLEDGE.org

Email: editorial@thescholedge.org

CPublisher

\title{
Factors Impeding Food Security in Akutupa-Kiri, Nigeria
}

\author{
OLORUNFEMI, Samuel Oluwaseyi \\ Department of Transport Management Technology \\ Federal University of Technology Akure, Nigeria.
}

\begin{abstract}
There has been refurbished interest in food security related issues in many developing countries of the world. In fact, the concern about the eradication of poverty and hunger form a major objective of the Sustainable Development Goals (SDGs). Yet poverty and hunger still persist due to food shortage and insecurity as a result of increased global food demand, diminishing global food reserves, erratic climatic condition, and increased cost of transportation among others. Before now, various agricultural policies measures have been formulated to curb food security challenges in Nigeria. Unfortunately, these policies have not produced the desired results of the increase in food production. This study examined the factors impeding food security in Akutupa-Kiri, Nigeria. A structured and selfadministered questionnaire using systematic sampling technique was used to collect data from a total of 194 (one hundred and ninety-four) household heads farmers representing $2 \%$ of the entire population in the study area. The data were presented using descriptive statistics in the form of frequency and percentages. Weighted means were used to determine the predominant factors impeding food security in the study area. Findings revealed that poverty (M.W=5.00), poor road transportation (M.W=5.00), inadequate social amenities (M.W=5.00) and lack of government support and assistance (M.W=5.00) were the most significant factors impeding food security in Akutupa-Kiri. The study recommends that there is a need for improvement in sustainable food security in the study area and Nigeria at large through the provision of adequate road transportation. Effort should be made by the government to render substantial support to the peasant farmers and as well ensure that agricultural policies formulation target these peasants farmers and their rural environments for the purpose of sustainable food security in the nation.
\end{abstract}

Keywords: Food security, farmers; food distribution; Akutupa-Kiri

\subsection{Introduction}

Food accessibility is a problem for everyone and especially for the developing world (Abdullah et al., 2017). As a matter of fact, food is an essential requirement for the survival of mankind and is different from other commodities because of its certainty for survival and existence of man (Otaha, 2013). The need for the eradication of poverty and hunger forms a major objective of the Sustainable Development Goals (SDGs) for Africa. Most rural areas in Africa constitute people who are poor and suffer a great deal of hunger. Nevertheless, these Africa rural areas are capable of offering the greatest potential for the sustainable development of the continent through increased agricultural production only if it is supported by adequate agricultural policies (Angmor, 2012)

According to Fadipeet al. (2014) social and economic stability of any country is largely dependent on the ability of that nation to ensure that its people have both physical and economic access to food that is adequate quantitatively and qualitatively. This is because food remains the most vital need for human existence apart from clothing and shelter. It is a known fact that the pitiless expedition for food has shaped human history, provoking wars, driving migration and underpinning the growth of nations (Eme et al., 2014). 
Nigeria, like some other developing countries, is principally an agrarian nation which still faces an everincreasing food crisis as the level of food production is yet to keep pace with demand. There is degeneration of food security, even with massive food importation as evidenced by rising food import bill (Okoye, et al., 2008). Fadipeet al. (2014) noted that Nigeria as a nation has a land area of 98.3 million hectares out of which 74million hectares is good for farming but less than half of this land is being explored. The population engaged in farming is about 60$70 \%$. Nigeria is endowed with Crop, livestock, and fish that have the potential for providing food and nutrition. Yet there is the threat of hunger and poverty because $70 \%$ of the population live below the average of 100 U.S Dollars per day.

Aderibigbe (2001) observed that before the discovery of crude oil, the nation flourished on agriculture with great concern for regional diversities in the form of agricultural produce within each region. With the oil boom, the public policy changed, relegating agriculture and other natural resources to the background. Consequently, most men left rural areas for urban areas in search of jobs in companies. Farming, especially the production of food crops, was left in the hands of the women producers. This led to a drastic reduction in the production of food and cash crops in Nigeria. Akinsanmi (2009) reported that Nigeria is one of the worst-hit countries globally given her unprecedented level of acute food shortage and its accompanying ravaging malnutrition. Though endowed with a vast expanse of arable land for crop production and fresh waters for fish breeding, reports still show that as Africa's largest country, it cannot produce food crops her population requires, thus has been depending on food importation to meet her domestic demands (Adepoju and Awodunmuyila, 2008). Despite the advanced growth in food production globally, Sub-Saharan Africa is the only region where hunger has risen in the last decade. The challenge today is that high food prices will cause an increase in food insecurity and widespread food crisis in many developing countries. Poor people in developing countries spend between 50-80\% of their income on food to meet their dietary need (Eme et al., 2014)

Various development-oriented policies have been implemented in Nigeria to curtain food security challenges. Some of the policies include the River Basin Development Authorities (RBDAs), The National Accelerated Food Production (NAFPP), Directorate for Food, Road and Rural Infrastructure (DFRRI), The National Directorate for Social Mobilization, The Better Life Programme, Agricultural Development Programmes (ADP) and the Cassava Multiplication Programme (CMP) among others. Available reports show that many aspects of agricultural production, such as cultivation, marketing, processing, etc. were covered (ADP, 2005). Unfortunately, these policies have not produced the desired results of increasing food production. The issue of food security has become a global debate that needs adequate attention for the world to survive. According to Eme et al. (2014), the global food crisis has been attributed to a number of factors including climate change, population growth, increased demand for biofuels, failure to improve crop yield, high oil prices, under-investment in agriculture, and poor implementation of agricultural policies among others. It is against the aforementioned, that the research seeks to study the factors that are impeding food security in Akutupa-Kiri Nigeria.

\subsection{Literature Review}

Food security has to do with the provision and access to nutritionally sufficient and culturally accepted food by each member of the household for healthy life obtained through socially acceptable ways (Abdullah $e t$ al., 2017). Andohol (2012) emphasizes the definition of food security and tailored it to the definition of the World Food Summit held in Rome in 1974 to mean the right of everyone to have access to safe and nutritious food, consistent with the right of everyone to be free from hunger. A household is considered food secure when its occupants do not live in hunger or fear of starvation (FAO, 2001) Food insecurity means the uncertain or limited access to nutritionally adequate and safe food ( FAO, 2006). Food security is multidimensional in nature and that makes accurate measurement and policy targeting quite challenging for the policymakers. However, food security means "consistent, dependable access to enough food for active, healthy living" (Coleman et al., 2011). Idachaba, (2006) sees food security as a situation that exists when all people, at all times, have physical, social, and economic access to sufficient, safe, and nutritious food that meets their dietary needs and food preferences for an active and healthy life.

According to Otaha (2013), food security includes a minimum of the ready availability of nutritionally adequate and safe foods on the assurance of the ability to acquire such foods in socially acceptable ways that are without resorting to emergency food supplies, scavenging, stealing or other cropping strategies. Agbo(2002) defines food security as a means by which people at all times have access to sufficient food for a healthy and productive life. Andohol (2012) opined that it is in the intention of Food and Agriculture Organization (FAO) that for a country to attain sustainable food security, food supplies must keep pace with increased population and urbanization. This implies that agriculture and population growth is vital to achieving food security. Gokum(2007); Andohol (2012) noted that the food security concept took its roots from the discussions of International food problems around mid- 
1970s at a time of global food crisis and adopted the definition of the World Food Summit in 1974 that food security is the availability of adequate world food supplies of basic food stuff at all times to sustain a steady expansion of food consumption and to offset fluctuation in production and prices. Corroborating the above, FAO (2002) pithily captures the definition of food security concept by stating that food security exists when all people at all times have physical, social and economic access to sufficient, safe and nutritious food that meet their dietary needs and food preferences for an active and healthy life.

According to Abdullah et al. (2014), food insecurity has become a global concern due to the increasing number of people that are undernourished amounting to 842 million, approximately $12 \%$ of the total world's population. The authors further noticed that developing countries are intensely affected with the issue of food insecurity as it is revealed in the case of Asia and Africa where more than $92 \%$ of the world's undernourished people are living. Corroborating the above, Andohol (2012) quoting FAO (2006) noted the highest incidence of hunger in sub-Saharan Africa, where one in every three persons suffers from chronic hunger and the greatest number of undernourished is in South Asia measured at about 299 million and closely followed by East Asia at 255 million people. The author further revealed that in Nigeria with a population of 140 million, about 50 million people suffer from extreme hunger. Andohol (2012) further discovered that Burundi, Ethiopia, Kenya, Madagascar, Nigeria, Sudan, Tanzania, and Zambia all have negative per capita annual growth rates in staple food of between -1.0 to $1.7 \%$ from 1995-2004.

Ema et al. (2014) studied challenges of food security in Nigeria (option before government). The authors relied on existing literature for their study and find out that the causes of food insecurity in developing nations are the inability of people to gain access to food due to prevalent poverty and unemployment. The authors also considered climate change as a factor impeding food security and as it affects pests, crops diseases, crop production, animal husbandry, and humans. Changing climatic conditions affect both the physical and economic availability of certain preferred food items. Findings also revealed that the rural people who are the active stakeholders in food availability account for 33.4 percent and are mainly involved in subsistence farming. The inconsistency in the government's targeted policy intervention and implementation strategies further compounds the problem of food security. The authors opined that the consequences of the above are what results in global food prices that have increased drastically in the last few years. Related to high food prices is the high cost of input which limits yield and production levels that many time leads to sub-optimal input utilization and production.

Abdulmuthallib (2014) examined the Strategy for Ensuring Food Security in Taraba State, Nigeria. The study identified several strategies for ensuring food security in the state and also identified factors affecting food security. These factors according to the author include climate change; inadequate health facilities; poor state of farmers' health; gender bias; bad roads; poor educational infrastructure; and lack of modern technology. Others are conflict or violence; political instability poverty; poor market accessibility; inflation; low access to farm inputs; high cost of farm inputs; low access to credit facilities; poor storage facilities for farmers; high cost of farm labour; high incidence of pests and diseases infestations; insufficient land for farming; poor soil fertility; and poor mechanization of farm operations. The author adopted a survey method for the study and structured questionnaire was designed and administered on 120 household heads that were randomly selected in each of the seven zones selected for the study area. The authors used descriptive analytical statistical methods and weighted mean to analyze the data obtained. Findings revealed that the most severe factors to food security were climate change $(M=3.61)$ and poor mechanization of farm operations ( $M=3.42)$. Meanwhile, the author failed to provide information on the intensity of damage caused by the above factors in the study area. In conjunction with the above, Otaha (2013) also noted gender inequality, policies inconsistencies and corruption, poverty and hunger, conflicts and natural disasters as a major factor hindering food security in Nigeria.

Otaha (2013) further identified the weaknesses and threats to Agricultural development in Nigeria to include: (a) poor access to credit, technical inputs, machines and farm implements (i.e. fertilizers, seeds, pesticides, tractor, plow, harvesters etc) by farmers (b) Degradation of agricultural natural resources especially soil and water bodies. (c) Poor infrastructure (i.e. rural roads, water supply, storage facilities, and market infrastructure) (d) Bad and inconsistent government policy (e) Poor budget allocation to the agricultural sector (f) Poor and inadequate irrigation facilities and (g) Uncontrolled grazing and livestock migration. The author concludes that in order to transform Nigeria agricultural sector and make it more attractive to people (especially the youth and unemployed), it is recommended that all tiers of government (Federal, State and Local), as well as public and private organizations, should sincerely adopt policies and strategies that will address and reduce the above weaknesses and threats to agriculture.

For adequate food security USAID, (2011) suggests several key steps to increasing agricultural productivity which will, in turn, increase income and reducing food insecurity. These include: improving agricultural science and technology; securing property rights and access to finance; enhancing human capital 
through education and improved health; conflict prevention and resolution mechanisms and democracy and good governance based on principles of accountability and transparency in public institutions and the rule of law are basic to reducing vulnerable members of society

\subsection{Study Area}

Akutupa Kiri is a village and the headquarters of Kiri land in Kabba/Bunu Local Government Area of Kogi State, Nigeria and situated at $8^{\circ} 27^{\prime} \mathrm{N} 6^{\circ} 24^{\prime} \mathrm{E}$ with a population of 4,725 (NPC, 1991). The language of Akutupa- Kiri is Yoruba while their local language is called Kiri and their traditional occupation is farming and this is due to the favorable climatic condition coupled with the fertile land that supports agricultural production (Sibiri et al, 2014). The road that links Akutupa-Kiri with neighboring communities is a federal road and it transverse through IlukeBunu and terminated at Egan in Lokoja Local Government Area of Kogi State. Having realized the potentials and socio-economic activities of the people along the route, the Federal Government approved the construction of the road from Ayetoro- Gbede in Ijumu Local Government to Eggan in Lokoja Local Government Area of Kogi State.

The construction started in 2001 and about 50km of the road was constructed and this terminated at Suku in Kabba-Bunu Local Government area of the state, while another part of the road was abandoned up to this moment. This situation has worsened the mobility of people residing along the route (Akutupa-Kiri inclusive). The poor condition of the road leading to the study area has not only hindered the mobility of the people in the area but has also denied them access to market, hospital and other social amenities such as telecommunication services that could aid the development of the area. The map below shows the Kabba-Bunu Local Government in its National Setting and Akutupa-Kiri the study location

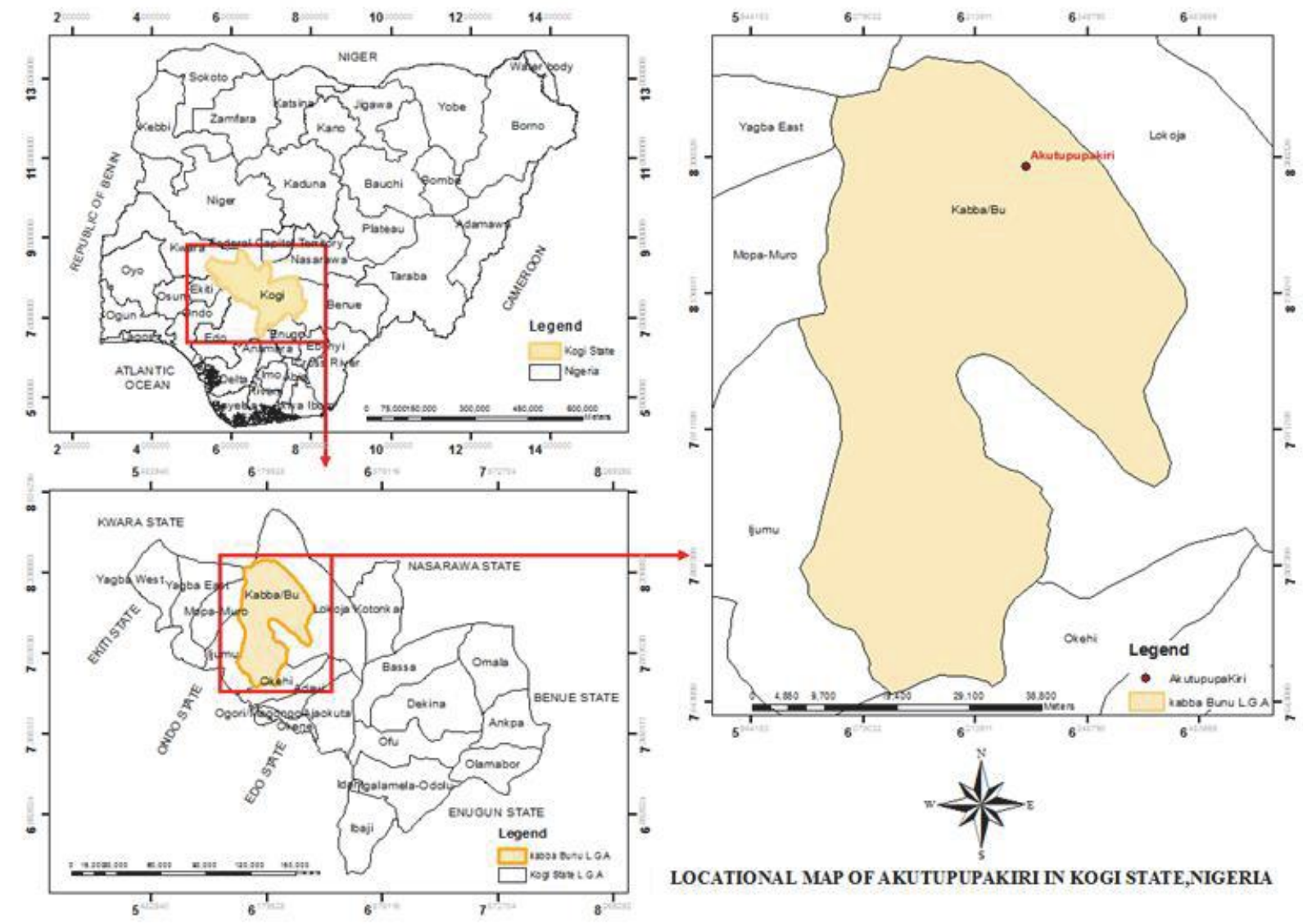

Figure 1: Locational Map of Akutupa-Kiri, Nigeria.

Source: Adapted from Gbadamosi and Olorunfemi, (2016). 


\subsection{Research Methodology}

The research adopts survey approach and data were sourced using both primary and secondary sources. The primary sources used to consist of personal observation and questionnaire administration. The questionnaire captured information on the social-economics characteristic of the respondents who are majorly farmers in the study area;labour used in farming, support from private or government; food security challenges in the study area, etc. and the secondary sources involves the use of relevant textbooks, journals, and internet. The population of Akutupa-Kiri is 4,725 (NPC, 1991). The target population and the population framework of the study consist of the entire population of Akutupa-Kiri who are majorly farmers.

In order to determine the sample size for the study, the 1991 population census figure (4,725) of AkutupaKiri was sourced for; and projected to the year 2017 at a growth rate of 2.8 which equal to 9,688 people out of which $2 \%$ of the household heads were sampled. The reasons for the adoption of 1991 population census figure was due to the fact that 1991 population figures were presented on towns/villages basis while that of 2006 population census results were presented on Local Government basis. In all, one hundred and ninety-four (194) farmers who are household heads were selected for questionnaires administration using a systematic sampling method. Based on the $2 \%$ sample that was selected for the study, respondents (household heads) were picked at every $3^{\text {rd }}$ interval of building in Akutupa-Kiri. The data collected were presented using descriptive statistics consisting of frequency counts and percentages. Factors impeding food security in the area were measured in five points likert scale ( $1=$ Strongly Disagree; $2=$ Disagree; $3=$ Undecided; $4=$ Agree, and 5= Strongly Agree) and the weighted mean was used to determine the predominant factors impeding sustainable food security in the area.

\subsection{Findings and Discussion \\ 5.1 Socio-Economic Characteristics}

The information in Table 5.1 shows the summary of the socioeconomic characteristics of household farmers who were surveyed for the study. The variables examined include sex, marital status, age, educational status, income and years of experience. The sex of the farmers in the study revealed that $54.12 \%$ were male and $46.00 \%$ were female. This shows that males were more involved in farming activities in Akutupa-Kiri than their female counterpart. This may be to the fact that males are more active and can withstand the rigor of farming than females and being the head of the family, has to provide for the family while females support in their own little ways. To corroborate this, Asogwa (2012) asserted that men mostly engaged in farming activities for income generation and the upkeep of their families. The investigation into their marital status shows that $28.00 \%$ were single, $56.00 \%$ were married, $1.00 \%$ divorced and $11.00 \%$ were widowed. This implies that married people were actively engaged than other segments in the study area.

The educational status of the respondents shows that $34.00 \%$ had no formal education, $46.00 \%$ possessed primary school education, $14.43 \%$ had secondary education and $6.00 \%$ acquired tertiary education. This indicates that the majority of respondents are primary school certificate holders which implies that they did not receive enough education to enable them to grapple modern agricultural production techniques. This may result from government policy to provide free primary education for her citizens. The high rate of poverty is also responsible for the low level of education acquired by the farmers owing to the fact that the pursuit of higher education is capital intensive. As a result of the above, many of the inhabitants in the study area took up farming as an occupation because of their inability to afford the cost of pursuing secondary/tertiary education.

The age revealed that $10.00 \%$ of them fall within the age bracket of $20-30$ years, $16.00 \%$ were within $31-40$ years and $40-50$ years respectively, $37.11 \%$ were discovered to be $51-60$ years and $21.13 \%$ fall within 60 years and above. This shows that the majority of the respondents in the area fall within the age bracket of 46-60 years. This implies that there is an inadequate engagement of active youths in farming in Akutupa-Kiri. This may be due to the absence of social amenities to motivate them to stay in the study area. As such, the majority of them relocate to the urban centers where they can enjoy such amenities. These pose a threat to food security and sustainable food development in Nigeria. However, this situation calls for policy to encourage the youths to participate in farming by making rural areas conducive for living through the provision of infrastructures. This has to be done because the mass rural-urban drift will impact negatively on sustainable development of food production in Nigeria (Olorunfemi and Adenigbo, 2017)

A look at the number of years of farming experience indicated that the majority $(52.10 \%)$ of the household farmers surveyed had spent more than 15 years in farming as an occupation in the study area. The highest earners among them are those that earn between $\$ 400,001-\$ 500,000$ annually. Others earned between 100,001- N200,000 (15.00\%), 200,001- 300,000 (18.00\%), $\$ 300,001-\$ 400,000(31.00 \%)$ and only $1.00 \%$ of the respondents earned 500,000 and above. For instance, if the annual income is put at $\$ 500,000$, it implies a daily income of $\$ 1$, 369 , which translate to about 3.8USD per day at the current exchange of $\$ 365$ to a Dollar. Note that this annual 
income is for households with the highest income in the study area, which means others live far below this threshold. With this, the level of poverty of rural farmers in Nigeria can, therefore, be imagined.

Table 1: Socio-Economic Characteristics of the Respondents (Household Heads)

\begin{tabular}{|c|c|c|c|}
\hline & & Frequency & Percentage \\
\hline \multirow[t]{4}{*}{1.} & Sex & & \\
\hline & Male & 105 & 54.12 \\
\hline & Female & 89 & 46.00 \\
\hline & Total & 194 & 100.00 \\
\hline \multirow[t]{6}{*}{2.} & Marital Status & & \\
\hline & Single & 54 & 28.00 \\
\hline & Married & 108 & 56.00 \\
\hline & Divorced & 10 & 1.00 \\
\hline & Widowed & 22 & 11.00 \\
\hline & Total & 194 & 100.00 \\
\hline \multirow[t]{7}{*}{3.} & Age & & \\
\hline & 20-30 Years & 21 & 10.00 \\
\hline & 31-40 Years & 30 & 16.00 \\
\hline & 41-50 Years & 30 & 16.00 \\
\hline & 51-60 Years & 72 & 37.11 \\
\hline & Above 60 Years & 41 & 21.13 \\
\hline & Total & 194 & 100.00 \\
\hline \multirow[t]{6}{*}{4.} & Educational Status & & \\
\hline & No Former Education & 65 & 34.00 \\
\hline & Primary School & 90 & 46.40 \\
\hline & Secondary School & 28 & 14.43 \\
\hline & Tertiary & 11 & 6.00 \\
\hline & Total & 194 & 100 \\
\hline \multirow[t]{7}{*}{5.} & Annual Income Status & & \\
\hline & $\$ 100,001-\mathrm{N} 200,000$ & 25 & 13.00 \\
\hline & $\$ 200,001-\$ 300,000$ & 34 & 18.00 \\
\hline & N300,001- $\$ 400,000$ & 60 & 31.00 \\
\hline & $\$ 400,001-\$ 500,000$ & 85 & 44.00 \\
\hline & 500,000 and Above & 10 & 1.00 \\
\hline & Total & 194 & 100.00 \\
\hline \multirow[t]{6}{*}{6.} & Years of Farming Experience & & \\
\hline & Less than 5 Years & 12 & 6.20 \\
\hline & 5-10 Years & 26 & 13.40 \\
\hline & 11-15 Years & 55 & 28.40 \\
\hline & 15 Years & 101 & 52.10 \\
\hline & Total & 194 & 100.00 \\
\hline
\end{tabular}

Source: Author's Field Work, 2017

\subsection{Labour Used and Support from Private organization/Government for Agricultural Production}

The types of labour used (see fig.2a) by the household farmers in Akutupa-Kiri revealed that all the household farmers surveyed used manual labour for their agricultural production which is mostly acquired through hired workers, family members or exchange labour with the use of simple farm implement such as cutlass, hoes, etc. The outcome of this is that there will be low agricultural productivity compared to when the mechanized system of farming is adopted. Looking at the support for agricultural production in the area (Fig 5.2b), it was discovered that $55.15 \%$ of the household farmers claimed they did not receive support either from private organization or government while $20 \%$ of them affirmed they received support. This implies that the farmers in the area live by selfsustenance alone since no support is received from the government or private organization(s). On those that received support (Fig.5.2c), the investigation into types of support received indicated that majority (46.40\%) received crops seedlings; cassava stem, etc. follow by free labour $(33.00 \%)$. Other support received includes 
Agrochemical (7.00\%) and loan/money (14.40\%). Sources of support (Fig. 5.2d) received show that the majority $(90.00 \%)$ of them received the support from their friends and family.

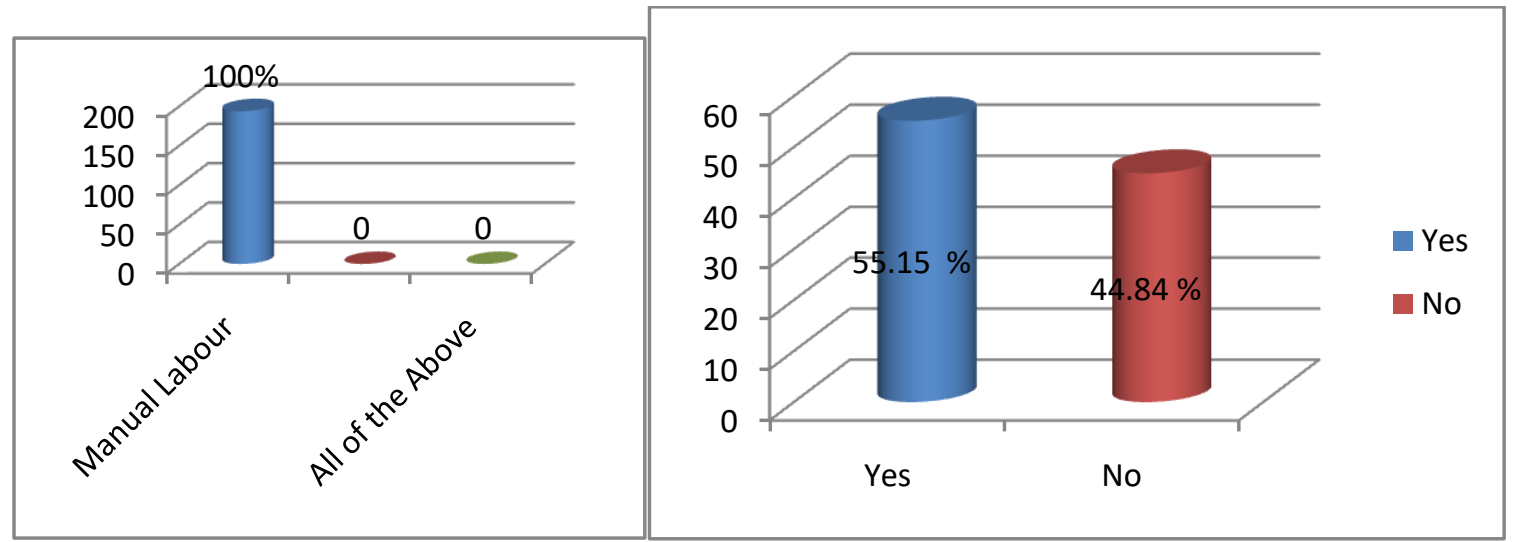

Fig 2a: Labour Used for Agricultural Production

Fig 2b: Support from Private/ Government

Source: Author's Field Work, 2017

Source: Author's Field Work, 2017

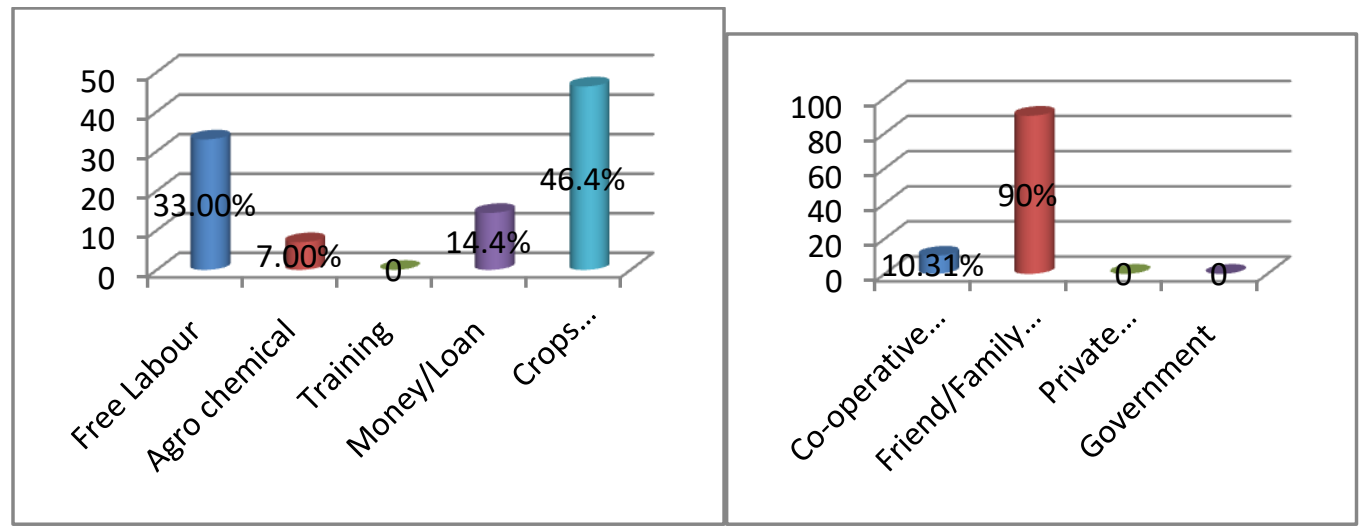

Fig. 2c Form of Support Received

Source: Author's Field Work, 2017

Fig. 2d: Source of Support Received

Source: Author's Field Work, 2017

\subsection{Factors impeding Food Security in Akutupa-Kiri}

It is pertinent to note that factors impeding food security vary from one place to another. This is in agreement with the statement of Agada (2012) that food security is a multidimensional phenomenon covering climate change, civil unrest, disaster and social norms along with food production, access, and utilization, and its determinants are different from one location to another, ranging from global, regional, national, household and individual levels.

However, Table 2revealed the factors impeding food security in Akutupa-Kiri, Nigeria. These factors were equally ranked using a weighted mean in order to determine how severe it is on food security in the area. The factors identified in the study area include climate change; poverty; illiteracy; use of manual tools/equipment; poor road transportation; inadequate social amenities (such as hospital, market, electricity, good road etc.); lack of storage facilities; lack of technological know-how; lack of government support and assistance; and others identified to be domestic thief and herdsmen. Among this factors, poverty (M.W=5.00), poor road transportation (M.W=5.00), inadequate social amenities (M.W=5.00) and lack of government supports and assistance (M.W=5.00) ranked first as the most significant factors impeding food security in Akutupa-Kiri. Corroborating the above findings in respect of poor road transportation, Gbadamosi and Olorunfemi (2016) discovered that Akutupa-Kiri road is characterized by inadequate road infrastructures and this is due to the fact that large section of the road leading to the area is untarred and this impedes easy vehicular and passenger movement. The condition of the road is worrisome as most passengers (including farmers) and drivers struggle to ply the road particularly during the rainy season. The authors further revealed that lack of social amenities is a challenge to the development of Akutupa-Kiri. 

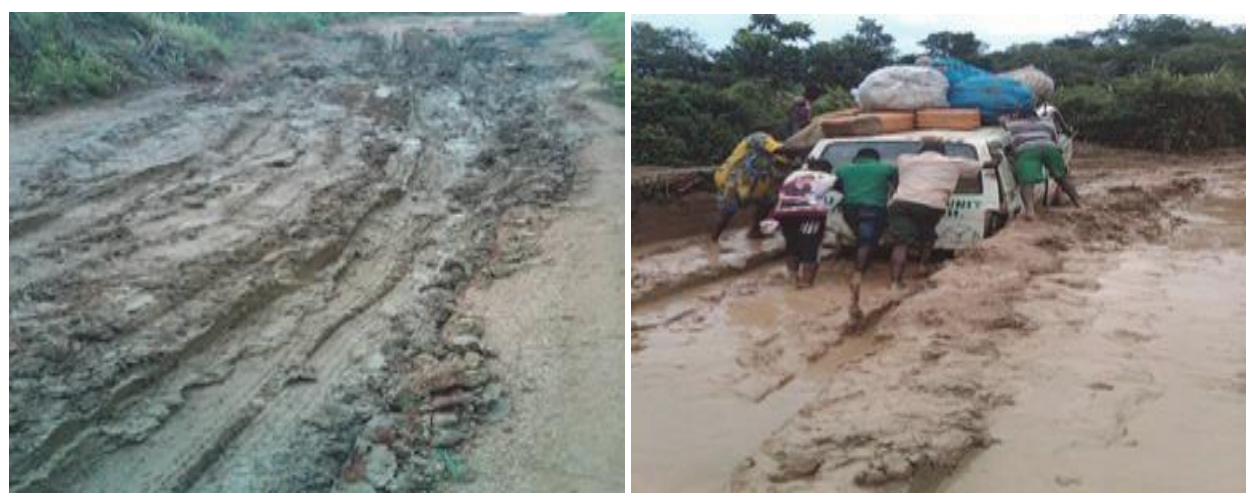

Figure 3: Road condition and passengers experience along Akutupa-Kiri road during the rainy season.

Source: Adapted from Gbadamosi and Olorunfemi (2016)

Apart from the above, poverty is equally prevalent in the study area. The study carried out by Otaha (2013) revealed that poverty and hunger prevent people from working hard to increase productivity. Food and agricultural productivity is both capital and labour intensive. The author further noted that it is the poor peasant farmers that produce the bulk of food needs in Nigeria, due to their level of poverty, they find it very difficult to learn, work and care for themselves and their family members, let alone getting the necessary inputs and energy to produce for others.

Lack of government support and assistance in enhancing food security in the area is also a problem as claimed by the farmers in Akutupa-Kiri. As a result of the above, Adewole (2015) stressed that there is a need for several policies and diverse support to boost agricultural production and enhance food security in Nigeria. This policies and support according to the author, will help to develop domestic industries that will be involved in the production of value-added products such as fruits, ethanol, and glucose syrup to encourage rural industrialization and rural job creation that will, in turn, enhance rural income and reduce rural-urban migration and poverty. Unfortunately, this has not been achieved due to the level of corruption in the country where farmers were unable to receive the right incentive and support for the growth and sustainability of agricultural production.

Furthermore, the use of manual tools and equipment $(\mathrm{M} . \mathrm{W}=4.90)$ ranked second among the factors impeding food security in the study area. The implication of this is that there will be low output in food production because the method is time-consuming and labour intensive. This is in consonance with the findings of Olorunfemi and Adenigbo (2017) that most farmers in Nigeria relied on the use of manual tools for their agricultural production and this is because the majority of them are financially poor to purchase high sophisticated equipment for agricultural purposes. This explains why most of them are peasant farmers.

Lack of storage facility (M.W=4.51), lack of technology know-how (M.W=4.51) and others (identified to be domestic thieves and herdsmen) (M.W=4.51) ranked third among the factors impeding food security. Majority of the farmers in the area affirmed that there is serious problem hindering optimum agricultural productivity as most of the farm produce in the study area waste away as a result of lack of storage facilities. Supporting the fact above, Sadiq (2013) observed that Nigeria produces a lot of tuber and cash crops such as yam, cassava, orange, mango, etc. but the majority of it wasted and rotten away in the farm due to poor storage facilities. Lack of technological knowhow is also a problem to maximum output because most of the farmers in the area are not fully educated to the level where they can conveniently handle modern agricultural production techniques. Also, domestic thieves coupled with herdsmen problem are issue contributing negatively to the food security in the area. No wonder, Abdulkadir (2014) noted that rural dwellers are not spared from the incessant robberies and banditry which has become a common phenomenon in Nigeria.

Climate change (M.W=4.39) ranked fourth. Climate change has a great effect on food production. Otaha (2013) opined that frequent climate changes leading to a shortage of rainfall and persistence drought in Northern part of Nigeria and excessive rainfall and flood in southern and middle belt regions of the country contributed immensely to low food production in Nigeria. Also, Sadiq (2013) stressed that forest destructions, excess bush burning, and over-grazing of animals have turned a lot of farmlands in Nigeria into deserts. This poses a serious threat to food security in the country. Poor implementation of agricultural policies (M.W=4.0) ranked fifth among the factors impeding food security in Akutupa-Kiri. Regrettably, many policies that were formulated for the purpose of improving agricultural development and alleviating poverty in Nigeria failed to achieve its goals; this is perhaps due to poor implementation process or corruption. Illiteracy (M.W=3.40) ranked sixth and the least among the 
factors impeding food security in Akutupa-Kiri. The level of illiteracy can be measured through the educational level of the farmer and looking at that majority of the farmer surveyed in the area had a primary school certificate. This may tell on their farming systems and outputs.

Table 2: Factors impede Food Security in Akutupa-Kiri

\begin{tabular}{|c|c|c|}
\hline $\begin{array}{l}\text { Factors impede Food Security in } \\
\text { Akutupa-Kiri }\end{array}$ & Weighted Mean Value & Rank \\
\hline Climate change/Natural Disaster & 4.32 & 4 \\
\hline Poverty & 5.00 & 1 \\
\hline Illiteracy & 3.28 & 6 \\
\hline $\begin{array}{l}\text { Use of manual tools and } \\
\text { equipment }\end{array}$ & 4.44 & 2 \\
\hline Poor road transportation & 5.00 & 1 \\
\hline $\begin{array}{l}\text { Inadequate social amenities such } \\
\text { as road, electricity, hospital, } \\
\text { market, communication network, } \\
\text { etc }\end{array}$ & 5.00 & 1 \\
\hline Lack of storage facility & 4.41 & 3 \\
\hline $\begin{array}{ll}\text { Poor implementation } & \text { of } \\
\text { agricultural policies } & \end{array}$ & 3.35 & 5 \\
\hline Lack of technological know-how & 4.41 & 3 \\
\hline $\begin{array}{l}\text { Lack of government support and } \\
\text { assistance }\end{array}$ & 5.00 & 1 \\
\hline $\begin{array}{l}\text { Others (domestic farm thief and } \\
\text { herdsmen }\end{array}$ & 4.41 & 3 \\
\hline
\end{tabular}

Source: Author's Field Work, 2017

\subsection{Conclusion and Recommendation}

This study has carefully examined factors impeding food security in akutupa-Kiri, Nigeria. Findings show that majority of the household heads farmers used simple farm implements and manual labour for their farming activities and a large number of them did not receive support from government while few that received support were assisted by their friends and family members to boost their farming activities. Findings also indicate that poverty, poor road transportation, inadequate social amenities and lack of government support and assistance were ranked first among the factors impeding food security in Akutupa-Kiri. Use of manual labour ranked second, lack of storage facilities, lack of technology know-how, domestic thieves and herdsmen ranked third, climate change ranked fourth, poor implementation of agricultural policies ranked fifth and the least ranked among the factors was illiteracy.

To solve the challenges militating against food security in the study area and in Nigeria at large, there is a need for improvement in sustainable food security through the provision of adequate road transportation facilities. This will involve the construction, expansion, and maintenance of Akutupa-Kiri road. This can be achieved through the mutual partnership of Kogi state Government with Kabba-Bunu Local Government. This will create an access opportunity for the farmers to transport their farm produce to the urban market where there is high demand for food as well as boosting agricultural production which will in turn increase farmers' income and thereby reduce poverty among farmers.

Effort should be made by the government to assist and render substantial support to the peasant farmers, knowing full well that in Nigeria, most of the food needed is produced by peasant farmers who are scattered all over the rural areas. As such, agricultural policies formulation should target these peasants' farmers and their rural environments for the purpose of sustainable food security in the nation. More so, storage facilities such as silo should be provided in the study area for the farmers to store their farm produce in order to reduce wastage of agricultural product.

Social amenities such as good road, market hospital, electricity, water, recreation area, police post should be provided in the area and in all rural areas in Nigeria, as this will motivate farmers most especially the young once to stay in the rural area and engage in farming activities to enhance food security and as well reduce rural-urban migration. 
The government should enforce a law that will guide against un-necessary bush burning, deforestation, over-grazing of farmland in order to rejuvenate the soil fertility for efficient output of the agricultural product. Extension workers should be empowered to training rural farmers on the new technology that can boost agricultural production for the sustainable development of food security in Nigeria.

\section{References}

[1]. Abdullah, Deyi, Z., Tarig, S., Sajjad, A., Waqar, A., Izhar, U., and Aasir, L., (2017). Factor affecting household food security in rural northern hinterland of Pakistan. Journal of the Saudi Society of Agricultural Sciences (2017),http://dx.doi.org/10.1016/j.jssas.2017.05.003

[2]. Abdulkadir,B.U (2014). Analysis of Condition of Rural RoadTransport in Kwara State, Nigeria.European Scientific Journal 10 (5):288-307.

[3]. Abdulmuthallib, U. I (2014). Strategy for Ensuring Food Security in Taraba State, Nigeria. Published Master Thesis Submitted to the Department of Agricultural Extension, University Nigeria, Nsukka.

[4]. Adepoju, A.A. and Awodunmuyila, D.J (2008). Economics of Cocoyam Production and Marketing in Ekiti East Local Government Area, Ekiti State, Nigeria. Research Journal of Applied Sciences 3(2): 95-98.

[5]. Aderibigbe, Y (May 2001). 'Resource control: looking beyond the lure of crude oil', Guardian, 17 May 2001: pg 8-9.

[6]. Adewole, E.A (2015).Regional Productivity and Marketing of Cassava in Ikere Local Government Area, Ekiti State, Nigeria. Master Thesis Submitted to the Department of Urban and Regional Planning, Federal University of Technology Akure, Nigeria

[7]. Akinsanmi, G (2009) Nigeria: Food Security - Transforming Potentials to Empowerment. Retrieved March 16, 2018, from http://www.allafrica.com/nigeria/

[8]. Agada M (2012). Socio-economic and cultural analyses of food security among selected ethnic groups in north-central Nigeria. Ph.D. research findings seminar presented to the Department of the Agricultural Extension University of Nigeria Nsukka.

[9]. Agbo, O (2002), "The Political Economic of Food Security in Nigeria" (unpublished) M.Sc. Thesis Department of Political Science, Benue State University Makurdi.

[10]. Agricultural Development Programme (2005). Annual report of the Abia State Agricultural Development Programme, Umuahia, Abia State, Nigeria

[11]. Andohol, J (2012).Nigeria's Food Security Programs: Implications for MDG's Goal of Extreme Hunger Eradication. International Journal of Business and Social Science 3( 9):243-253

[12].Angmor, E.N (2012) The Role of Road Transportation Service in the Development of Traditional Market's: A Case of Asesewa and Agormanya Traditional Markets in the Eastern Region, Ghana. Master Thesis Submitted To TheSchool Of Graduate Studies, Kwame Nkrumah University Of Science And Technology, Ghana.

[13].Asogwa, B.C, Ezihe, J.A, and Ater, P.I (2013).Socio-economic Analysis of Cassava Marketing in Benue State, Nigeria.International Journal of Innovation and Applied Studies 2 (4): 384-391.

[14].Coleman-Jensen, Alisha, Nord, Mark, Andrews, Margaret, Carlson, Steven, (2011).Statistical Supplement to Household Food Security in the United States in 2010:AP-057. USDA, Economic Research Service http://www.ers.usda.gov/

[15].Eme, O I., Onyishi, T., Uche, O. A., and Uche, I. B (2014). Challenges of Food Security in Nigeria: Options before Government. Arabian Journal of Business and Management Review 4 (1):15-25

[16].Fadipe A.E.A, Amolegbe K.B., and Afun O.O. (2014). Food Security and University Agricultural Students Involvement In Food Production After Graduation.Journal Of Research In Forestry, Wildlife And Environmental 6 (1) 67-81.

[17]. Gbadamosi, K..T, and Olorunfemi, S.O (2016). Rural Road Infrastructural Challenges: An Impediment to Health Care Service Delivery in Kabba-Bunu Local Government Area of Kogi State, Nigeria.Academic Journal of Interdisciplinary Studies 5(2):34-43

[18].Gokum, G.G. (2007), “Agricultural Development Programmes and Food Security in Nigeria

[19].(1970-2004)" in Ogiji, P. (ed.), the Food Basket Myth: Implications for Food Security and Agricultural Reforms in Nigeria, Makurdi: Aboki Publishers.

[20].Food and Agriculture Organization (FAO). (2001). Perspective study on Agriculture Development in the Shellian Countries Vol. 3

[21].Food and Agriculture Organization (FAO). (2006). The state of food insecurity in the world. Food and Agriculture Organization of the UnitedNations, Rome.

[22].Idachaba, F. S. (2006). Strategic and Policies for Food Security and Economic Development in Nigeria. Lagos: CBN.

[23]. Okoye, B. C., Asumugha, G. N. Okezie, C. A., Tanko, L. and Onyenweaku, C. E. (2008). Econometric Assessment of the Trend in Cocoyam Production in Nigeria,1960/1961 - 2003/2006. Agricultural Journal 3 (2): 99-101.

[24].Olorunfemi, S.O, and Adenigbo, J.O (2017).Road Transportation Challenges to Food Security in Ikere Ekiti Local Government Area of Ekiti State, Nigeria. Paper presented at the Quantitative Methods for Integrated Food and Nutrition Security Measurements-Lessons to be learned Conference organized by European Commission and International Food Policy Research Institute held at Thon Hotel Brussels, $15^{\text {th }}-17^{\text {th }}$ November 2017. 
[25].Otaha, I. J. (2013). Food Insecurity in Nigeria: Way Forward. An international multidisciplinary Journal, Ethiopia. 7 (4): 26-35

[26].Sadiq C.O (2013). Major Problems of Food and Agriculture in Nigeria. Retrieved from the www.thenigeriavoice.com/privacy-cookies.asp on 26th February 2018.

[27].Sibiri, A. E., Ayinmoro, A. D, Jack Jackson, T. C. B (2014).The Socio-Cultural Effects of Internal Migration among the People of Akutupa Kiri in the North-Central Zone, Nigeria. Mediterranean Journal of Social Sciences, $15(15)$.

[28].USAID (2011). Promoting Food Security in Sub-Saharan Africa. The Journal Outlook on Agriculture vol. 27 